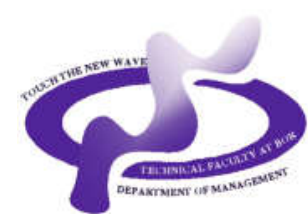

www.sjm06.com
Serbian

Journal

of

Management

\title{
FDI DETERMINANTS IN EUROPE AND CHINESE INFLUENCE
}

\author{
Alena Dorakh* \\ Trier University, Universitätsring st.,15 D-54296 Trier, Germany
}

(Received 21 September 2020; accepted 08 March 2021)

\begin{abstract}
Despite recent concerns about the increasing influence of outside investors on the European Union (EU) and Western Balkans, the developed European countries are still a dominant source of foreign direct investment (FDI) in the region, confirming the benefits of EU membership. At the same time, fast-growing connectivity and lower trade costs in accession and neighboring countries determine the FDI growth from China, particularly via the Belt and Road Initiative (BRI). By applying panel data over 2000-2019 for 34 countries, which form $89 \%$ of all European FDI, we first examine FDI patterns around Europe, compare the EU, NMS, and Western Balkans; verify the importance of EU membership for FDI, caused reducing trade costs and improving connectivity. Thus, the new EU member states (NMS) and Western Balkans appear both as a home country and as a pre- entry destination to the EU. Then, we calculate trade costs indices for each selected country and partners over time and find that Europe and China are closely interconnected through trade and FDI. It means that stronger ties with China can be realized for the sample countries at the cost of easing relations with the EU. Finally, incorporating trade costs indices into the FDI model; we evaluate the impact of connectivity on FDI and estimate how BRI affected FDI in Europe. Additionally, we validate that the old framework of horizontal and vertical FDI not representative well and even new complex vertical or export-oriented FDI strategies are shifting today.
\end{abstract}

Keyword: FDI, trade costs, connectivity, Chinese investment, horizontal, vertical, and exportoriented strategies, the Belt and Road Initiative (BRI), fixed and random effects

\section{INTRODUCTION}

While global foreign direct investment (FDI) after the sizable declines modestly increased in 2019, FDI flows in Europe

\footnotetext{
*Corresponding author:s4aldora@uni-trierde
}

DOI: $10.5937 /$ sjm16-22279 raised much by 18 percent (\%), mostly driven by increasing FDI flows to the European Union (EU) and neighboring countries (World Investment Report, 2020). Nonetheless, FDI inflows and outflows fell 
in some principal developed European economics. The shock of the pandemic adds to the volatility of FDI.

Traditionally, the Netherlands, Germany, France, and Italy attract about $42-48 \%$ of FDI flows in the EU-28 economy; and together with Luxembourg and Spain, invest more than $50 \%$ of all outflows from the EU. The dominant FDI strategy seems to be horizontal (market-seeking) FDI, where economy size matters.

Since the middle of the 2000s, with EU enlargements, there has been a shift in the European FDI landscape, as EU membership spurred FDI growth to the accession countries by reducing trade costs and eliminating investment barriers. In 2007, for the first time, FDI to the new EU member states (NMS) accounted for more than 50\% of GDP, making EU membership a key FDI determinant.

Trade costs as a proxy for connectivity in the EU have become one of the most influential FDI determinants. On the one hand, lower trade costs promote marketseeking (horizontal) FDI, since investors avoid the existing tariff and non-tariff barriers in the host country and access new markets. On the other hand, reduced trade costs boost efficiency-seeking (vertical) FDI via lower production and operation costs and differences in factor endowments.

Improving connectivity led to decreasing FDI flows to the EU as a whole and partially reorienting investors towards new EU member states (NMS) (Estonia, Latvia, Lithuania, Czechia, Slovakia, Poland, Hungary, Slovenia, Romania, Bulgaria, and Croatia), candidate countries (Albania, Montenegro, North Macedonia, Serbia), and potential candidates (Bosnia and Herzegovina and Kosovo) (Figure 1).

As illustrated in Figure 1, with decreasing FDI flows to the EU as a whole, investment to NMS increased in 2016-2018 an average by $10 \%$ and more than by $25 \%$ to Western Balkans, respectively. Starting from the point that for transition countries, perhaps, market growth potential and trade costs are more valuable than market size, the preferential strategy became complex and exportoriented FDI.

Most of FDI inflows to NMS and Western Balkans originated in developed EU member countries. However, since 2013 the Belt and Road Initiative (BRI) has adopted, FDI to BRI countries increased sharply, making connectivity the main of the influential FDI

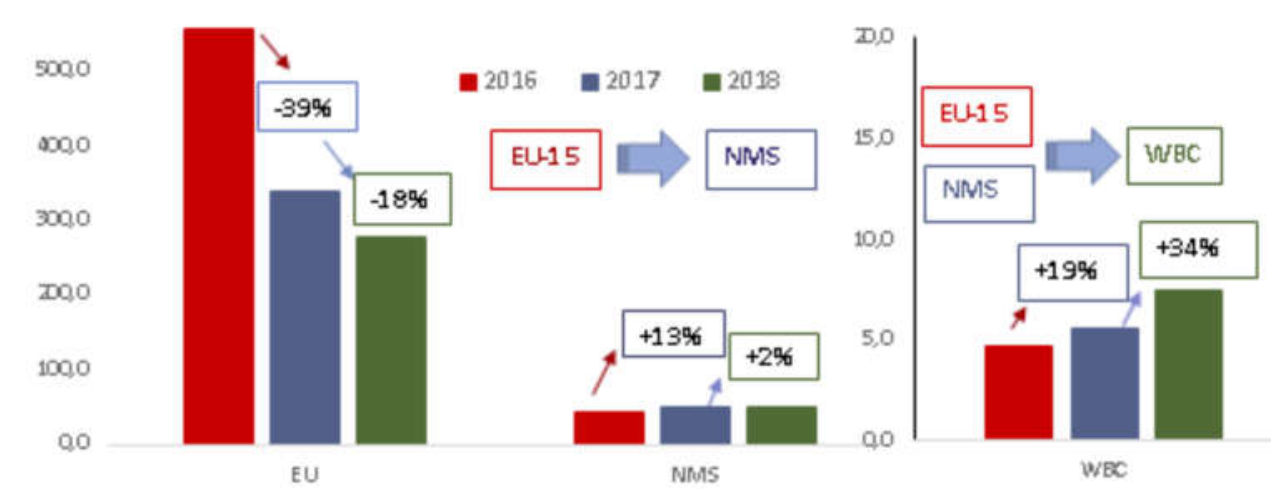

Figure 1. Dynamic of FDI inflows to the EU, NMS, and WBS (millions of dollars)

Source: prepared by author based on the World Bank's and UNCTAD Data 
factors. As a result, the share of Chinese investment in the region, mostly asset- and market-seeking FDI, has doubled over the last five years. Czechia, Hungary, Poland, and Serbia are the largest recipients of Chinese investment. For the first time, the Western Balkans' share of FDI in transition economics between 2013 and 2019 increased from 8 to $13 \%$ (World Investment Report, 2020). A large number of the projects target export-supported FDI.

The most prominent factor for extra-EU investors, mostly for China, is that Western Balkans, as candidate countries to the EU, have a unique position because specific trade and FDI restrictions do not apply to them, but access to the European market is available. At once, FDI inflows, as a share of GDP, grow much faster in Western Balkans than in the EU or the World. Thus, Europe and Asia are highly interconnected, thereby China expanding its influence in trade and FDI through the far-reaching connectivity concept.

And today, the same determinants that propelled the early growth of FDI, namely, trade liberalization and fragmentation of production, started pushing in the opposite direction, with a return of protectionist tendencies. It will imply a shift from expooriented and efficiency-seeking FDI to regional market-seeking FDI and infrastructure investment. Connectivity, relocation, and redistribution, as well as technology, will become dominant FDI factors.

In this paper, we analyze patterns and determinants of FDI in Europe, in particular, the roles of trade costs and connectivity in determining the volume of FDI, and compare impacts of EU- and BRI membership in shaping FDI patterns across European countries.
Stimulated by the influential FDI papers, we create panel data for 35 countries over 2000-2019, and combining it with calculated trade costs indices, empirically explore the heterogeneity across different types of FDI determinants as well as across countries and time. The paper is structured as follows. In Section II, we provide the most influential FDI theories and review the literature. In Section III, we describe the stages of the analysis and report empirical results. In Section IV are conclusions and policy implication.

\section{THEORY AND EMPIRICAL STUDIES OF FDI}

Determinants of FDI vary across countries and regions and change their nature over time. To explain the phenomenon of FDI, a large number of theoretical models were developed, including neoclassical trade theory, market imperfections, product lifecycle theory, and eclectic paradigms. In the strictest version of the neoclassical theory, the poorest countries should have the highest return to capital, and for this, attract most FDI. However, over the last five decades, developed countries, which are capital-abundant, have received a larger share of FDI flows (World Investment Report, 2020). Alternatively, within the theory of industrial organization, many conceptual frameworks have been proposed, but here FDI is motivated only by firmspecific factors without including factors for host countries.

The canonical model for determinants of FDI begins from the earlier research work of Dunning (1973), which provides a comprehensive analysis based on ownership, location, and the internationalization (OLI) 
paradigm. According to the theory, there are two main reasons why firms internationalize production: market-seeking and efficiencyseeking. Given the multinational nature of the foreign firms, Markusen (1984, 2000) construct a horizontal FDI model, suggesting that companies prefer to enter the foreign market via FDI rather than via export with higher trade costs. Market size and access to new countries seem to be the more common reasons for multinational FDI activity. Hence, horizontal firms intend to improve connectivity but save trade costs (transportation costs, tariffs, investment barriers).

A counterweight, Helpman (1984, 2006) introduces vertical FDI where transport costs and tariffs are assumed away, so production facilities are not established to save transport costs but based on a difference in relative factor endowments. So, vertical FDI and trade costs are negatively related. It means reducing trade costs increase connectivity that, in turn, boosts FDI. This approach was later extended by Markusen (2002), combined horizontal and vertical models into the Knowledge Capital Model (KC), where all types of multinational companies can coexist, based on various host- and sourcecountry characteristics. Another valuable extension of the $\mathrm{KC}$ model has supported Baltagi, et al. (2007), who implies complex vertical FDI with relocation production processes in different neighboring countries with more promising endowments. Blonigen et al. (2007) suggest export platform FDI, where trade costs are low enough between several host potential destination markets compared to the trade costs between the home and destination countries. In that case, the multinational firm will select the most favorable destination market to serve other host markets through exports.
The prevailing ownership-based theories of FDI are increasingly are being challenged by new forms of technologies, infrastructure investment, reducing trade costs, and development of the Asian network multinational enterprises (World Investment Report, 2020).

The existence of multilateral FDI strategies has significant implications for empirical studies on FDI. While a vast literature suggests that the major determinants of FDI inflows include the macroeconomic variables, such as economic size and growth (Bevan et al., 2004; Blonigen and Piger, 2014), labor force and human capital (Jirasavetakul \& Rahman, 2018), international trade (Asiedu, 2002, 2006), and infrastructure development (Canh et al., 2020); in a few papers, the impact of EU membership on FDI is analyzed (Cardamone \& Scoppola, 2012; Bruno et al., 2017; Welfens \& Baier, 2018); and to date, no study exists that focuses on whether and how connectivity in determining the volume of FDI, comparing impacts of EU- and BRI membership in shaping FDI patterns across Europe.

Connectivity initiatives are the latest and modern tool for advancing influence in international trade and FDI, and this paper aims to contribute to this growing related literature. This article sets out to provide more clarity about the connectivity in the EU, distinguishing between developed EU countries and NMS as well as comparing NMS and the candidate countries (Western Balkans). Particular focus will be placed on connectivity as a degree of economic integration in Europe in recognition of Chinese influence.

Current existing studies (Bevan et al., 2004; Bruno et al., 2017; Mistura \& Roulet, 2019) estimate the effects of EU integration 
with gravity models. Borrowing this approach from the international trade studies, the FDI gravity equation is extensively applied. But understanding the average effects of determinants on FDI across Europe, country-specific factors need to be considered. In gravity models, individual country factors usually are hidden in the fixed effects estimates. Specifically, to obtain more reliable FDI estimates, we simultaneously tested the random-effects model as well as the fixed-effects model. This is because the role of EU membership is not equal across Europe. In addition to the previous literature, we split the impact of EU integration among the new and old EU member states as well as the candidate countries. For this, we suggested different samples and used various methods to compare results with each other and with existing studies.

Most importantly, in addition to existing studies, we formulated and estimated the FDI model in Europe with Chinese influence. For this, we estimate the potential effect of trade costs on FDI as a proxy for connectivity since trade costs include FDIrestrictive measures for countries. A negative relationship between restrictions and value of trade has been observed mostly in the existing trade but not FDI literature. Moreover, the trade studies concentrated mostly on advanced economies; the few studies - on the EU, without consider the candidate EU countries and potential candidate. This paper adds to the literature by extending the assessment to groups of advanced EU countries, NMS and Western Balkans and distinguishing between impacts of EU- and BRI-membership on FDI.

Based on the paper by Novy (2011), we calculated and presented indices of total bilateral trade costs for selected countries with respect to their trade partners, and second, evaluated the impact of connectivity on FDI by incorporating trade costs into the baseline empirical model. Thus the elasticity of connectivity between EU members, nonmembers, and non-continental large trade and FDI partners, especially China, provides a quantitative measure for better understanding and comparing the depth of EU integration and the BRI project.

European integration has a different realization between FDI inflows to the developed EU countries, the new EU member states, and Western Balkans (Jirasavetakul \& Rahman, 2018). To apply this idea to the BRI concept, by panel data analysis, we show that at the beginning, there was a lower amount of Chinese investments to NMS and Western Balkans but when BRI was adopted, FDI to the region increased sharply, making connectivity one of the significant FDI determinants.

Besides the traditional FDI determinants, we also develop and test some factors, which connect with digital infrastructure and relocation of international production (Kano $\&$ Oh, 2020). This is based on the premise that FDI may be shifted from expo-oriented and efficiency-seeking FDI to regional market-seeking FDI in Europe.

\section{EMPIRICAL ANALYSIS OF FDI DETERMINANTS AND RESULTS}

To investigate the key factors that affect FDI across Europe, we present a series of empirical applications and create different samples. The idea is that if we think of the EU as the Single market, then FDI would be presented both horizontal and vertical FDI strategies, consolidated in the KC model. But when we add Western Balkans and 
disaggregate samples, we then see the export-platform phenomenon and complex vertical FDI. Another reason for disaggregating is that there are important differences between Chinese investment behavior in the developed EU countries, NMS, and Western Balkans. Thus, baseline FDI sample covered 34 countries: EU-28 and 6 Western Balkans, including the further split between EU-28, EU-13, and Western Balkans. Selected countries form $89 \%$ of all European FDI, so the sample seems to be highly representative. Frequency of the data is annual and it is from 2000 to 2019 for all the constituent countries (except Kosovo, due to unavailability of data).

The study is based on the secondary transparent data collected from the World Bank Indicator databank and Penn World Table 10.0 (Feenstra et al., 2015). Since the single FDI dataset for NMS as well as for Western Balkans is nonexistent, we separately bring together scattered data from the national banks and agencies of the host countries. Missing FDI values were reflected by zeros (Bevan et al., 2004).

Baseline equation takes the following functional form:

$\ln F D I_{i, t}=\beta_{0}+\beta_{1} \ln G D P_{i, t}+\beta_{2} \ln G D P P_{i, t}$ $+\beta_{3} U L C_{i, t}+\beta_{4}$ HCapital $_{i, t}+\beta_{5}$ OFDICh $_{i, t}{ }^{+}$ $\beta_{6}$ Ports $_{i, t}+\beta_{7}$ Internet $_{i, t}+\beta_{8} E U_{i, t}+\beta_{9} B R I_{i, t}+$ $\beta_{10}$ Openness $_{i, t}+\beta_{11} I C T_{i, t}+\beta_{12}$ Railway $_{i, t}{ }^{+}$ $\beta_{13}$ HiTech $_{i, t}+\beta_{14} t_{i j}+U_{i}+U_{t}+\varepsilon_{i, t}$,

where the dependent variable is logarithm of FDI net inflow (million US dollars), $U_{i}$ are individual (random and fixed) effects, $U_{t}$ are time effects, and $\varepsilon_{i, t}$ is error term, which determines whether appear fixed or random effects. A detailed description of the independent variables that are expected to determine FD is presented in Table 1.
Since the goal of the analysis, besides others, is to quantify the Chinese influence on FDI and verify the role of connectivity, BRI, and infrastructure in determining the FDI patterns for selected countries; we try to provide a full set of potential factors and possible effects. First of all, with a new emerging FDI literature, China's outward FDI $(O F D I C h)$ was included. We suggest that Chinese FDI tend to be attracted to all countries across Europe, which have access to the Single Market since trade costs fall. Lowering trade costs $\left(t_{i j}\right)$ as a proxy for improving connectivity, might be a key FDI factor.

For each year in the period 2000-2018, based on the model by Novy (2011), total bilateral trade costs for 35 countries and their partners were calculated. A particular focus was placed on connectivity with China as the principal trade and investment partner. On the one side, in general, trade costs indicate the degree of European integration among the all EU countries as well as between NMS and candidates. On the other side, a change in trade costs might provide measure for Chinese influence and the BRI efficiency in Europe. Specifically, if country properly uses BRI funds for improving infrastructure, it can further enhance the economic attractiveness of the country to FDI.

To measure connectivity, besides the effects of the EU integration and BRI participate, a physical infrastructure quality (Ports, Railway) as well as a digital infrastructure (Internet, ICT, HiTech) have been estimated. Remarkable, relationships between transportation cost, infrastructure, connectivity and FDI received far less attention. Using these variables, we try to show a clear and positive correlation between European integration, cooperation with China, and regional differences in 
Table 1. Potential determinant variables of FDI inflows

\begin{tabular}{|c|c|}
\hline $\begin{array}{c}\text { Explanatory } \\
\text { variables }\end{array}$ & Description \\
\hline $\operatorname{lnGDP}$ & $\begin{array}{l}\text { The country-specific nominal GDP (in logarithmic form), (million US. dollars). World Bank } \\
\text { Data }\end{array}$ \\
\hline $\operatorname{lnGDPP}$ & $\begin{array}{l}\text { GDP per capita (in logarithmic form), based on purchasing power parity (million U.S. dollars). } \\
\text { World Bank Data }\end{array}$ \\
\hline ULC & Average annual hours worked by persons engaged (hours). PWT 10.0 \\
\hline HCapital & $\begin{array}{l}\text { Human capital index, based on the average years of schooling and an assumed rate of return to } \\
\text { education. PWT } 10.0\end{array}$ \\
\hline OFDICh & $\begin{array}{l}\text { Chinese investment (in logarithmic form), net FDI outflows (million U.S. dollars). World Bank } \\
\text { Data }\end{array}$ \\
\hline Ports & $\begin{array}{l}\text { Quality of ports: range from } 1 \text { (extremely underdeveloped) to } 7 \text { (well developed and efficient by } \\
\text { international standards). World Bank Data }\end{array}$ \\
\hline Internet & Individuals using the Internet (in logarithmic form), $\%$ of population. World Bank Data \\
\hline EU & $\begin{array}{l}\text { EU membership: dummy variable, that takes a value of } 1 \text { if the country in the EU, and zero } \\
\text { otherwise. An official website of the EU: https://europa.eu/european-union/index_en }\end{array}$ \\
\hline BRI & $\begin{array}{l}\text { BRI membership: dummy variable, that takes a value of } 1 \text { if the country in the BRI, and zero } \\
\text { otherwise. Countries that joined the BRI by signing a Memorandum of Understanding with } \\
\text { China. https://green-bri.org/countries-of-the-belt-and-road-initiative-bri/ }\end{array}$ \\
\hline Openness & $\begin{array}{l}\text { Trade openness is the sum of exports and imports of goods and services as a share of gross } \\
\text { domestic product, (\% of GDP): calculated by author based on the World Bank Data. }\end{array}$ \\
\hline & Openness $=(($ Export + Import $) / G D P) * 100 \%$ \\
\hline ICT & $\begin{array}{l}\text { Information and communication technology exported ( } \% \text { of total goods exports), including } \\
\text { computers and peripheral equipment, communication equipment, and other information. World } \\
\text { Bank Data }\end{array}$ \\
\hline Railway & Railway goods transported (in logarithmic form), million ton per km. World Bank Data \\
\hline Hi-Tech & High-technology exports (\% of manufactured exports). World Bank Data \\
\hline Trade costs $\left(t_{i j}\right)$ & Indices of total trade costs for selected countries, calculated based on the paper by Novy (2011) \\
\hline
\end{tabular}

infrastructure adequacy. Apparently, all infrastructure indicators tend to be higher for higher-income countries. And while the average infrastructure quality of NMS and Western Balkans is below that of the developed EU countries, it might push them to be involved in the BRI projects.

Once an essential relationship between $E U, B R I$ memberships and the rate of connectivity is established, we estimate the model first for a pooled sample of countries and then separating EU-28, EU-13, and Western Balkans. Comparative FDI analysis, which at the same time indicates a degree of connectivity for selected countries, shows how the determinants of FDI vary both, within and outside of the EU as well as across BRI and non-BRI countries. Our special focus is to identify, whether NMS are more attractive to Chinese FDI than the Western Balkan region.

Performing separate analysis for the developed EU countries, NMS, and candidate countries makes it possible also to capture the effect of EU integration $(E U)$ on FDI. Thus, this operation allowed us to indicate the main differences in FDI activity both before and after EU enlargement. We 
start from the OLS model, which cannot be accepted as a benchmark, but it is necessary for comparing the results. In order to address the endogeneity problem, then a number of instrumental variables are included in the Two-Stage Least Squares (SLS).

Our results are reported in Table 2.

As seen from columns (1)-(8) of Table 2, on average, $70 \%$ of the variation of FDI flows in the sample countries is explained by the specifications. It confirms that selected variables are relevant determinants of FDI inflows in Europe. Following the idea that the importance of the determinants depends on the FDI strategy in home countries, we can suppose, that the old framework of horizontal and vertical FDI not representative well, and connectivity shifts even new complex vertical and exportoriented FDI strategies today.

Traditionally, GDP, as a proxy of market size, positively determines prospects for FDI. To measure the development and growth of the relative factor endowments is often GDP per capita used. As seen from columns (1-8) of Table 2, for all groups of countries coefficients of GDP are statistically significant and positive, while GDPP is negative for the EU-28 ( $\beta=-0.4307)$ and EU$13(\beta=-0.7526)$, and positive for Western Balkans $(\beta=1.2602)$. These estimates verify relationships between income country levels

Table 2. Panel estimation the determinants of FDI in selected countries

\begin{tabular}{|c|c|c|c|c|c|c|c|c|}
\hline Model & $\begin{array}{c}(1) \\
O L S\end{array}$ & $\begin{array}{l}(2) \\
S L S\end{array}$ & $\begin{array}{c}(3) \\
O L S\end{array}$ & $\begin{array}{c}(4) \\
S L S\end{array}$ & $\begin{array}{c}(5) \\
O L S\end{array}$ & $\begin{array}{c}(6) \\
S L S\end{array}$ & $\begin{array}{l}(7) \\
O L S\end{array}$ & $\begin{array}{l}(8) \\
S L S\end{array}$ \\
\hline Sample & \multicolumn{2}{|c|}{ All selected countries } & \multicolumn{2}{|c|}{ EU-28 } & \multicolumn{2}{|c|}{ EU-13 } & \multicolumn{2}{|c|}{ WB } \\
\hline Dep. var. & \multicolumn{2}{|c|}{$\ln F D I$} & \multicolumn{2}{|c|}{$\ln F D I$} & \multicolumn{2}{|c|}{$\ln F D I$} & \multicolumn{2}{|c|}{$\ln F D I$} \\
\hline $\operatorname{lnGDP}$ & $\begin{array}{c}1.0062 \\
(0.0562)^{* * *}\end{array}$ & $\begin{array}{c}0.9333 \\
(0.0768)^{* *}\end{array}$ & $\begin{array}{c}1.0917 \\
(0.0613)^{* *}\end{array}$ & $\begin{array}{c}0.9492 \\
(0.0811)^{* *}\end{array}$ & $\begin{array}{c}1.1288 \\
(0.0847)^{* *}\end{array}$ & $\begin{array}{c}1.0641 \\
(0.0948)^{* * *}\end{array}$ & $\begin{array}{c}0.5592 \\
(0.1448)^{* *}\end{array}$ & $\begin{array}{c}0.6958 \\
(0.1491)^{* *}\end{array}$ \\
\hline $\operatorname{lnGDPP}$ & $\begin{array}{c}-0.2393 \\
(0.1192)^{*}\end{array}$ & $\begin{array}{l}-0.1350 \\
(0.1408)\end{array}$ & $\begin{array}{c}-0.4307 \\
(0.1507)^{* *}\end{array}$ & $\begin{array}{c}-0.2284 \\
(0.1689)\end{array}$ & $\begin{array}{c}-0.7526 \\
(0.2308)^{* *}\end{array}$ & $\begin{array}{c}-0.7041 \\
(0.2333)^{* * *}\end{array}$ & $\begin{array}{c}1.2602 \\
(0.3950)^{* *}\end{array}$ & $\begin{array}{c}1.3472 \\
(0.3974)^{* * *}\end{array}$ \\
\hline ULC & $\begin{array}{c}-0.0006 \\
(0.0001)^{* *}\end{array}$ & $\begin{array}{c}-0.0006 \\
(0.0001)^{* *}\end{array}$ & $\begin{array}{l}-0.0011 \\
(0.0004)^{* *}\end{array}$ & $\begin{array}{c}-0.0012 \\
(0.0004)^{* *}\end{array}$ & $\begin{array}{c}0.0005 \\
(0.0006)\end{array}$ & $\begin{array}{c}0.0006 \\
(0.0006)\end{array}$ & $\begin{array}{l}-0.3122 \\
(0.1118)^{* *}\end{array}$ & $\begin{array}{l}-0.3001 \\
(0.1124)^{\text {*** }}\end{array}$ \\
\hline HCapital & $\begin{array}{c}-0.3626 \\
(0.1455)^{*}\end{array}$ & $\begin{array}{c}-0.3921 \\
(0.1472)^{* * *}\end{array}$ & $\begin{array}{c}-0.7067 \\
(0.1796)^{\text {** }}\end{array}$ & $\begin{array}{c}-0.7621 \\
(0.1818)^{* *}\end{array}$ & $\begin{array}{l}-0.4644 \\
(0.3821)\end{array}$ & $\begin{array}{l}-0.4224 \\
(0.3836)\end{array}$ & $\begin{array}{c}0.4949 \\
(0.2838)^{+}\end{array}$ & $\begin{array}{c}0.5622 \\
(0.2856)^{+}\end{array}$ \\
\hline OFDICh & $\begin{array}{c}-0.3043 \\
(0.0667)^{\text {*** }}\end{array}$ & $\begin{array}{c}-0.2774 \\
(0.0695)^{* * *}\end{array}$ & $\begin{array}{c}-0.2752 \\
(0.0791)^{* *}\end{array}$ & $\begin{array}{c}-0.2083 \\
(0.0833)^{*}\end{array}$ & $\begin{array}{c}-0.2234 \\
(0.1213)^{+}\end{array}$ & $\begin{array}{c}-0.1833 \\
(0.1243)\end{array}$ & $\begin{array}{l}-0.4675 \\
(0.1468)^{* *}\end{array}$ & $\begin{array}{c}-0.5127 \\
(0.1479)^{\text {** }}\end{array}$ \\
\hline Ports & $\begin{array}{c}0.1493 \\
(0.0430)^{* *}\end{array}$ & $\begin{array}{c}0.1455 \\
(0.0432)^{* *}\end{array}$ & $\begin{array}{c}0.0801 \\
(0.0488)\end{array}$ & $\begin{array}{c}0.0759 \\
(0.0491)\end{array}$ & $\begin{array}{c}-0.0294 \\
(0.0679)\end{array}$ & $\begin{array}{l}-0.0482 \\
(0.0691)\end{array}$ & $\begin{array}{c}0.1344 \\
(0.0733)^{+}\end{array}$ & $\begin{array}{c}0.1526 \\
(0.0738)^{*}\end{array}$ \\
\hline Internet & $\begin{array}{c}0.3221 \\
(0.1001)^{* * *}\end{array}$ & $\begin{array}{c}0.2878 \\
(0.1032)^{* *}\end{array}$ & $\begin{array}{c}0.5061 \\
(0.1900)^{* *}\end{array}$ & $\begin{array}{c}0.3810 \\
(0.1965)^{+}\end{array}$ & $\begin{array}{c}0.5435 \\
(0.2242)^{*}\end{array}$ & $\begin{array}{c}0.4959 \\
(0.2266)^{*}\end{array}$ & $\begin{array}{c}0.1382 \\
(0.1337)\end{array}$ & $\begin{array}{c}0.1072 \\
(0.1346)\end{array}$ \\
\hline $\mathrm{EU}$ & $\begin{array}{l}-0.1648 \\
(0.1584)\end{array}$ & $\begin{array}{l}-0.1410 \\
(0.1596)\end{array}$ & $\begin{array}{l}-0.3176 \\
(0.2149)\end{array}$ & $\begin{array}{l}-0.2485 \\
(0.2176)\end{array}$ & $\begin{array}{c}0.1641 \\
(0.2261)\end{array}$ & $\begin{array}{c}0.2048 \\
(0.2280)\end{array}$ & $\begin{array}{c}0.1389 \\
(0.2176)\end{array}$ & $\begin{array}{c}0.1153 \\
(0.2186)\end{array}$ \\
\hline BRI & $\begin{array}{l}-0.2839 \\
(0.1431)^{*}\end{array}$ & $\begin{array}{c}-0.3109 \\
(0.1446)^{*}\end{array}$ & $\begin{array}{c}-0.2808 \\
(0.1625)^{+}\end{array}$ & $\begin{array}{c}-0.3383 \\
(0.1647)^{*}\end{array}$ & $\begin{array}{c}-0.3923 \\
(0.1877)^{*}\end{array}$ & $\begin{array}{c}-0.4184 \\
(0.1887)^{*}\end{array}$ & $\begin{array}{l}-0.1895 \\
(0.2189)\end{array}$ & $\begin{array}{l}-0.1591 \\
(0.2201)\end{array}$ \\
\hline Openness & $\begin{array}{c}0.9854 \\
(0.1122)^{* * *}\end{array}$ & $\begin{array}{c}0.9122 \\
(0.1240)^{* *}\end{array}$ & $\begin{array}{c}1.2143 \\
(0.1251)^{* *}\end{array}$ & $\begin{array}{l}1.0667 \\
(0.1371)^{* *}\end{array}$ & $\begin{array}{c}0.9347 \\
(0.2332)^{* *}\end{array}$ & $\begin{array}{c}0.8842 \\
(0.2359)^{* *}\end{array}$ & $\begin{array}{c}-1.0696 \\
(0.3620)^{* *}\end{array}$ & $\begin{array}{c}-1.1567 \\
(0.3643)^{* *}\end{array}$ \\
\hline ICT & $\begin{array}{c}0.0408 \\
(0.0067)^{* * *}\end{array}$ & $\begin{array}{c}0.0419 \\
(0.0068)^{* *}\end{array}$ & $\begin{array}{c}0.0447 \\
(0.0071)^{* *}\end{array}$ & $\begin{array}{c}0.0474 \\
(0.0072)^{* *}\end{array}$ & $\begin{array}{c}0.0248 \\
(0.0084)^{* *}\end{array}$ & $\begin{array}{c}0.0258 \\
(0.0084)^{* *}\end{array}$ & $\begin{array}{c}0.1306 \\
(0.1941)\end{array}$ & $\begin{array}{c}0.0263 \\
(0.1966)\end{array}$ \\
\hline Railway & $\begin{array}{l}-0.0257 \\
(0.0324)\end{array}$ & $\begin{array}{l}-0.0018 \\
(0.0367)\end{array}$ & $\begin{array}{l}-0.0152 \\
(0.0394)\end{array}$ & $\begin{array}{c}0.0289 \\
(0.0429)\end{array}$ & $\begin{array}{c}-0.0859 \\
(0.0486)^{+}\end{array}$ & $\begin{array}{l}-0.0721 \\
(0.0495)\end{array}$ & $\begin{array}{c}-0.0758 \\
(0.0599)\end{array}$ & $\begin{array}{c}-0.0971 \\
(0.0604)\end{array}$ \\
\hline _cons & $\begin{array}{c}5.6240 \\
(1.5802)^{* *}\end{array}$ & $\begin{array}{c}5.9157 \\
(1.5962)\end{array}$ & $\begin{array}{c}6.0049 \\
(2.2159)^{* *}\end{array}$ & $\begin{array}{c}6.6280 \\
(2.2401)^{* *}\end{array}$ & $\begin{array}{c}4.0702 \\
(2.9589)\end{array}$ & $\begin{array}{c}4.1631 \\
(2.9635)\end{array}$ & $\begin{array}{c}7.3922 \\
(4.7941)\end{array}$ & $\begin{array}{c}4.7219 \\
(4.8589) \\
\end{array}$ \\
\hline$N$ & 606 & 606 & 498 & 498 & 229 & 229 & 108 & 108 \\
\hline $\mathrm{r} 2$ & 0.7178 & 0.7170 & 0.6721 & 0.6685 & 0.6075 & 0.6064 & 0.6779 & 0.6749 \\
\hline
\end{tabular}


and FDI across Europe, which is pointing to investors seeing better prospects in markets with lower income levels. As a first result, a negative sign of GDPP, as a proxy of country development, supports horizontal FDI for EU-28 and NMS, but a positive sign of GDPP - vertical FDI for Western Balkans. At the same time, according to the literature (Bruno et al., 2017), GDPP implies mostly growth of the relative factor endowments, specifically, labor cost, and consequently, if the coefficient GDPP negatively correlated with FDI, it might be evidence of the vertical FDI model. Indeed, larger labor cost makes the cost of production higher, hence, causes less FDI.

In support of this claim, unit labor cost $(U L C)$ was chosen as the proper measure of differences in factor endowments, rather than simple relative wage rates, since $U L C$ includes also non-wage labor costs. As expected, for all countries from the sample there is a negative correlation between FDI and $U L C$, but for $E U-13 \quad U L C$ is not significant that does not suggest clear vertical FDI. Just opposite, for Western Balkans the magnitude of the estimated coefficient $U L C$ is significant and visibly stronger. This means that the importance of the vertical reason for FDI inflows in the region is more pronounced then in the EU.

When lower $U L C$ is a key determinant for the increasing vertical FDI, human capital (HCapital) tends to matter considerably when strategic asset-seeking is an important investment motivation (Dunning, 1973; Dunning \& Lundan, 2008). From our results (Table 2), for all selected countries and EU28 HCapital is statistically significant and negative; for EU-13 this coefficient is not significant; and for Western Balkans it is positive. Dealing specifically with this issue, we suppose that for NMS labor-seeking motivation is a paramount reason underlying FDI inflows, and human capital may not matter much. At the same time, production becomes more capital-, knowledge-, and skill-intensive and needs a well-educated human capital. Thus, coefficient HCapital in Western Balkans, as a key factor of the participation in the Global Value Chain (GVC), is positive. Moreover, today digital platforms, data flows and data processing have changed the way firms interact, and lowered an importance of human component in production and investment (Kano \& Oh, 2020). Therefore, HCapital for EU-28 is significant but negative. As see, the relative importance of human capital (HCapital) and labor cost (ULC) as motivations for FDI are changing across time and between countries.

In the context of Chinese influence on FDI, a negative coefficient of human capital (HCapital) in EU-28 discourages vertical FDI but might suggest assets-seeing FDI (brands, distribution networks, etc.) in the developed EU countries.

Our empirical results pointed to a combination of efficiency-seeking, marketseeking, and assets-seeking strategies, setting the Knowledge Capital (KC) model of FDI for EU-28, while the FDI strategies for EU-13 and Western Balkans are not clear. In support of $\mathrm{KC}$, the coefficient of information and communication technology (ICT) is positive and significant for all countries from the EU. It is claimed that $I C T$ lowers the transaction and production costs of foreign investors and improves their access to information. Notably, ICT is not significant for Western Balkans, indicating that the region is motivated by more complex FDI. In this case, a type of FDI depends also on the country's degree of openness to trade. Openness to international trade (Openness) allows us to test for the 
differential relationship between FDI and trade across countries. Investors tend to invest in the trade partner markets with which they are familiar via export. For this purpose, the volume of trade is enhanced and thus Openness is expected to be a positive and significant FDI determinant. Indeed, as seen from Table 2, the coefficient Openness is positive for all countries from the EU and negative for Western Balkans. It confirms the benefits of the EU and Single Market in the traditional sense: foreign firms set production in the partner country in Europe to serve the European market. But when we focus on the candidate countries, trade and FDI could be substituted, much of FDI is export-oriented, applying complex and export-platform FDI in Western Balkans. Thus, Openness reflects EU membership that enlarges the potential market size for investments, reduces trade barriers, and improves connectivity. If countries form a free trade agreement, in our case, the European Single Market; the outside country may opt to build a plant inside the bloc and export to the other country in the EU (Blonigen et al., 2007). But the key assumption to drive the export-oriented FDI is a lower trade costs.

Nevertheless, our findings should be taken only as the first evidence and do not account for many elements including controls for time and country factors, as well as does not adjust for endogeneity concerns. That's why the coefficient of EU membership $(E U)$ is not statistically significant for all selected countries. To address the endogeneity problem, we apply the instrumental variable regression (SLS).

Since this study's aim is also to verify how connectivity in determining the volume of FDI in Europe, and whether impacts of BRI membership in shaping FDI patterns, the analysis focuses now on patterns of the Chinese FDI in Europe.

Results from Table 2 support the prediction of a negative relationship between the Chinese FDI outflow (OFDICh) and all FDI to selected countries, with a significant beta-coefficients' gap. Comparison of the estimated coefficients suggests that Western Balkans $(\beta=-0.467)$ are less vulnerable to the Chinese FDI shifting than all European countries $(\beta=0.275)$ and NMS $(\beta=0.223)$, respectively. A negative relationship supports the assumption that FDI inflows to Western Balkans as well as to the other countries originated not from China, but mostly from the developed EU countries.

With the Belt and Road Initiative (BRI) China is becoming an important player in Europe, particularly in NMS, where Western companies have slowly divested their engagement. Specifically, the regression coefficient BRI in Table 2 for EU-28 is significant at a $10 \%$ significance level, whereas that BRI for EU-13 is significant at a 5\% level, and this coefficient for Western Balkans is not significant. Important, it means, BRI facilitates access and fosters deeper economic connectivity between the EU and China. Plus, the coefficient BRI for EU-13 is higher than for EU-28. Thus, Chinese influence in the new EU member states felt more strongly than in all other countries across Europe. This implies that the new EU market is more attractive for Chinese infrastructure investment than Western Balkans. Negative coefficients BRI might be evidence of a higher degree of integration within the EU than BRIparticipate cooperation, and dominated investment from the EU.

However, the sample countries are highly heterogeneous, and interpretation of estimates might be distorted by the not 
appropriate estimation techniques. The SLS model seems more robust then OLS to the control variables but assumes that there are no differences among countries. These are all issues that will be tackled in further empirical analysis.

Our hypothesis is that the ability of countries to attract FDI and maximize the benefits of EU integration and BRI participation will depend on the connectivity of each country. Connectivity in terms of FDI typically is large than only improving infrastructure, thus, it is often difficult to estimate its impact. Cost analysis is one of the most commonly used and wellestablished techniques. For this, we estimate the potential effect of trade costs on FDI as a proxy for connectivity since trade costs include FDI-restrictive measures for countries.

First, we calculated indices of the total bilateral trade costs, which capture all the costs of trading a good between two countries relative to the cost of trading it domestically in each of the selected countries. Second, the impact of connectivity on FDI will be estimated by incorporating trade costs into the basic empirical model of FDI.

Trade costs $\left(t_{i j}\right)$ are derived from data on production and exports of manufactured goods based on the theoretical framework developed by Novy (2011). A particular focus on connectivity with China as the principal trade and investment partner is presented in Figure 2.

As illustrated in Figure 2, relying on fouryear averages, the difference in trade costs between China and the EU is largest in the period 2004-2008 with a drop of 23\%, while the largest varying in trade costs between the EU and Western Balkans is in the period 2008-2012 with a drop of 44\%. Indeed, with EU enlargements, trade costs decreased, promoting a shift in the European FDI landscape to the new EU member states. Similarly, in the period 2008-2012, when trade costs drop significantly, Albania, Montenegro, Serbia, and other countries from the region applied for EU membership. Preliminary results seem to point that EU membership is a key determinant of improving connectivity in Europe.

Besides this, the drop in trade costs

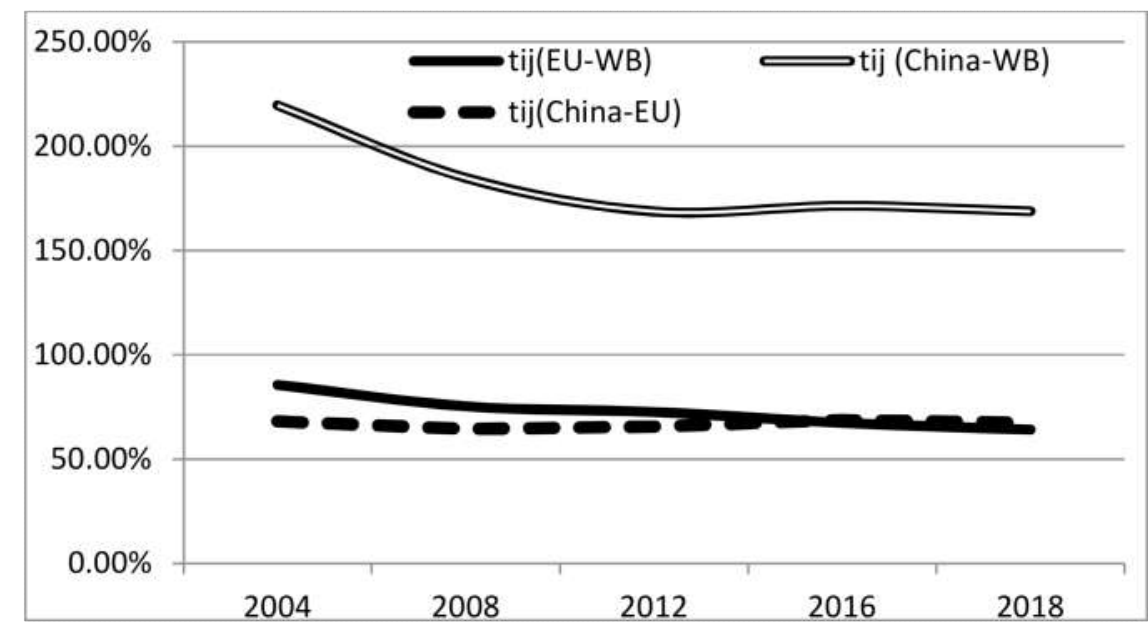

Source: calculated based on the paper by Novy (2011)

Figure 2. Trade costs for the EU, NMS, and WB (\%) 
between China and Western Balkans reflects also the Belt and Road Initiative (BRI), adopted in 2013. This result is supported by the trade theory that decreased trade costs should increase integration. To understand whether the change in trade costs and connectivity can serve as a proxy for the level of EU integration and determines the volume of FDI, we estimate our model by adding trade costs indices and including fixed and random effects.

To distinguish country-specific effects, first, we assume that individual effects are random and vary across countries. From this, we estimate the Random effects models (RE) for all groups of countries. Second, we suggest that individual country characteristics are invariant over time and employ the Fixed effects models (FE). Then, by comparing RE and FE models with the Hausman test, we obtain the efficient estimator. Finally, to control for policy changes such, as joining the EU, time effects are included. After these estimation experiments, for EU-28 as well as for EU-13 both RE and FE are consistent, but RE is efficient; while for Western Balkans FE is efficient.

Our FDI estimates are reported in Table 3.

As seen from columns (1)-(8) of Table 3, incorporating trade costs and certainly controlling for fixed effects makes it possible to capture a significant part of country factors that may influence FDI. Focusing on the impact of changes in trade costs (TCosts) on FDI, coefficient TCosts shows a consistent strong negative and significant effect on all groups of selected countries. It confirms that the trade costs (TCosts), among other factors, is one of the main relevant determinants of FDI inflows to Europe.

The negative relationship between trade costs and FDI turns out to be stronger for EU-13 than for Western Balkans (WB), both in terms of the slope of the regression line (for WB: $-23 \%$; for EU-13: $-94 \%$ ), and in terms of statistical significance. Namely, decreasing TCosts between NMS and China in $10 \%$ is associated with a $9.4 \%$ more FDI. The six Western Balkan countries have correspondingly higher trade costs with China than the EU average. In support of this prediction, the negative coefficient OFDICh for Western Balkans is higher than for EU13. If Chinese investment decreases by $10 \%$, the value of FDI to Western Balkans and EU13 from other sources (mostly, from the developed EU countries) increases by $5.2 \%$ and $2.1 \%$, respectively. Extensive supply chains and access to outside markets, supported by connectivity, create intensive for Western Balkans to further integration.

Additionally, reductions in trade costs could influence FDI through specific FDI motives and strategies. While high trade costs may motivate firms to replicate production across countries (horizontal FDI), decreasing in trade costs will allow firms to better exploit differences in factors endowments (vertical or complex FDI). In our case, negative coefficient TCosts, among other variables, gives support the prediction of $\mathrm{KC}$ model for EU-28 and vertical FDI for EU-13.

Western Balkans tend to facilitate vertical and export supporting FDI. The profitability of both strategies increases as trade costs fall. For export-platform FDI, the relationship is more ambiguous in the region. Nevertheless, investors, particularly from China, always seek to serve not only one country but the whole EU.

Most important, by incorporating TCosts into our specification, variables of EU membership $(E U)$ and the participation in 
Table 3. FDI estimates in selected countries

\begin{tabular}{|c|c|c|c|c|c|c|c|c|}
\hline & $\begin{array}{l}\text { (1) } \\
\text { RE }\end{array}$ & $\begin{array}{l}(2) \\
\text { FE }\end{array}$ & $\begin{array}{l}\text { (3) } \\
\text { RE }\end{array}$ & $\begin{array}{l}\text { (4) } \\
\text { FE }\end{array}$ & $\begin{array}{l}\text { (5) } \\
\text { RE }\end{array}$ & $\begin{array}{l}\text { (6) } \\
\text { FE }\end{array}$ & $\begin{array}{l}\text { (7) } \\
\text { RE }\end{array}$ & $\begin{array}{l}\text { (8) } \\
\text { FE }\end{array}$ \\
\hline Sample & \multicolumn{2}{|c|}{ All selected countries } & \multicolumn{2}{|c|}{ EU-28 } & \multicolumn{2}{|c|}{ EU-13 } & \multicolumn{2}{|c|}{ WB } \\
\hline Dep. var. & \multicolumn{2}{|c|}{$\ln F D I$} & \multicolumn{2}{|c|}{$\ln F D I$} & \multicolumn{2}{|c|}{$\ln F D I$} & \multicolumn{2}{|c|}{$\ln F D I$} \\
\hline $\operatorname{lnGDP}$ & $\begin{array}{c}0.6783 \\
(0.1343)^{\text {*** }}\end{array}$ & $\begin{array}{c}1.8020 \\
(1.2802)\end{array}$ & $\begin{array}{c}0.6469 \\
(0.1359)^{* *}\end{array}$ & $\begin{array}{c}3.0004 \\
(1.4746)^{*}\end{array}$ & $\begin{array}{c}0.8179 \\
0.0954)^{* *}\end{array}$ & $\begin{array}{c}2.0389 \\
(1.8883)\end{array}$ & $\begin{array}{c}0.8404 \\
(0.1855)^{* *}\end{array}$ & $\begin{array}{l}-0.3164 \\
(2.7303)\end{array}$ \\
\hline $\operatorname{lnGDPP}$ & $\begin{array}{c}0.1538 \\
(0.2204)\end{array}$ & $\begin{array}{c}-1.0332 \\
(1.2610)\end{array}$ & $\begin{array}{c}0.0936 \\
(0.2602)\end{array}$ & $\begin{array}{l}-2.1401 \\
(1.4571)\end{array}$ & $\left(\begin{array}{l}-0.5801 \\
(0.2391)^{*}\end{array}\right.$ & $\begin{array}{l}-0.5251 \\
(1.8426)\end{array}$ & $\begin{array}{c}0.4983 \\
(0.4589)\end{array}$ & $\begin{array}{c}0.3420 \\
(2.8822)\end{array}$ \\
\hline ULC & $\begin{array}{c}-0.0001 \\
(0.0002)\end{array}$ & $\begin{array}{c}0.0013 \\
(0.0014)\end{array}$ & $\begin{array}{c}-0.0008 \\
(0.0008)\end{array}$ & $\begin{array}{c}0.0021 \\
(0.0016)\end{array}$ & $\begin{array}{c}0.0006 \\
(0.0006)\end{array}$ & $\begin{array}{c}0.0019 \\
(0.0019)\end{array}$ & $\begin{array}{c}-0.3278 \\
(0.1092)^{* * *}\end{array}$ & $\begin{array}{c}0.3862 \\
(0.4887)\end{array}$ \\
\hline HCapital & $\begin{array}{l}-0.1286 \\
(0.2455)\end{array}$ & $\begin{array}{l}-0.0696 \\
(0.2923)\end{array}$ & $\begin{array}{l}-0.4680 \\
(0.3164)\end{array}$ & $\begin{array}{l}-0.4413 \\
(0.3979)\end{array}$ & $\begin{array}{c}-0.3018 \\
(0.3952)\end{array}$ & $\begin{array}{l}-0.3060 \\
(1.0481)\end{array}$ & $\begin{array}{c}0.5140 \\
(0.2852)^{+}\end{array}$ & $\begin{array}{c}0.2594 \\
(0.3032)\end{array}$ \\
\hline $\operatorname{TCosts}\left(t_{i j}\right)$ & $\begin{array}{c}-0.2503 \\
(0.0836)^{* *}\end{array}$ & $\begin{array}{c}-0.2553 \\
(0.0872)^{* *}\end{array}$ & $\begin{array}{c}-0.6900 \\
(0.2824)^{*}\end{array}$ & $\begin{array}{c}-0.1528 \\
(0.3089)\end{array}$ & $\begin{array}{l}-0.9442 \\
0.2619)^{* * *}\end{array}$ & $\begin{array}{l}-0.0711 \\
(0.3208)\end{array}$ & $\begin{array}{c}-0.1473 \\
(0.0736)^{*}\end{array}$ & $\begin{array}{c}-0.2389 \\
(0.0793)^{3 *}\end{array}$ \\
\hline OFDICh & $\begin{array}{c}-0.2383 \\
(0.0634)^{* * *}\end{array}$ & $\begin{array}{c}-0.2494 \\
(0.0728)^{* *}\end{array}$ & $\begin{array}{c}-0.1906 \\
(0.0775)^{*}\end{array}$ & $\begin{array}{c}-0.2278 \\
(0.0866)^{* * *}\end{array}$ & $\left(\begin{array}{l}-0.2127 \\
(0.1185)^{+}\end{array}\right.$ & $\begin{array}{l}-0.1978 \\
(0.1335)\end{array}$ & $\begin{array}{c}-0.5275 \\
(0.1570)^{* *}\end{array}$ & $\begin{array}{c}-0.2695 \\
(0.1498)^{+}\end{array}$ \\
\hline Ports & $\begin{array}{c}0.0772 \\
(0.0451)^{+}\end{array}$ & $\begin{array}{c}0.0802 \\
(0.0459)^{+}\end{array}$ & $\begin{array}{c}0.0561 \\
(0.0536)\end{array}$ & $\begin{array}{c}0.0653 \\
(0.0543)\end{array}$ & $\begin{array}{l}-0.1288 \\
(0.0704)^{+}\end{array}$ & $\begin{array}{l}-0.1317 \\
0.0715)^{+}\end{array}$ & $\begin{array}{c}0.1411 \\
(0.0794)^{+}\end{array}$ & $\begin{array}{c}0.0908 \\
(0.0765)\end{array}$ \\
\hline Internet & $\begin{array}{c}0.3539 \\
(0.0991)^{* *}\end{array}$ & $\begin{array}{c}0.3439 \\
(0.1047)^{\text {** }}\end{array}$ & $\begin{array}{c}0.2705 \\
(0.1967)\end{array}$ & $\begin{array}{c}0.3247 \\
(0.2111)\end{array}$ & $\left(\begin{array}{c}0.5344 \\
(0.2246)^{*}\end{array}\right.$ & $\begin{array}{c}-0.0976 \\
(0.2538)\end{array}$ & $\begin{array}{c}0.3157 \\
(0.1240)^{*}\end{array}$ & $\begin{array}{c}0.5819 \\
(0.1239)^{* * *}\end{array}$ \\
\hline HiTech & $\begin{array}{c}0.0059 \\
(0.0124)\end{array}$ & $\begin{array}{l}-0.0002 \\
(0.0141)\end{array}$ & $\begin{array}{l}-0.0021 \\
(0.0144)\end{array}$ & $\begin{array}{l}-0.0086 \\
(0.0169)\end{array}$ & $\begin{array}{c}0.0339 \\
(0.0150)^{*}\end{array}$ & $\begin{array}{c}0.0157 \\
(0.0192)\end{array}$ & $\begin{array}{c}0.0573 \\
(0.0222)^{* * *}\end{array}$ & $\begin{array}{c}0.0260 \\
(0.0218)\end{array}$ \\
\hline $\mathrm{EU}$ & $\begin{array}{l}-0.1975 \\
(0.1629)\end{array}$ & $\begin{array}{l}-0.1307 \\
(0.1743)\end{array}$ & $\begin{array}{l}-0.2230 \\
(0.2261)\end{array}$ & $\begin{array}{c}0.0238 \\
(0.2409)\end{array}$ & $\begin{array}{c}0.2136 \\
(0.2228)\end{array}$ & $\begin{array}{c}0.2970 \\
(0.2314)\end{array}$ & $\begin{array}{c}0.0685 \\
(0.2169)\end{array}$ & $\begin{array}{c}-0.4869 \\
(0.2470)^{+}\end{array}$ \\
\hline BRI & $\begin{array}{c}-0.2173 \\
(0.1313)^{+}\end{array}$ & $\begin{array}{l}-0.0934 \\
(0.1449)\end{array}$ & $\begin{array}{l}-0.1825 \\
(0.1586)\end{array}$ & $\begin{array}{c}0.1147 \\
(0.1799)\end{array}$ & $\begin{array}{c}-0.4699 \\
(0.1860)^{*}\end{array}$ & $\begin{array}{l}-0.1795 \\
(0.2052)\end{array}$ & $\begin{array}{l}-0.2749 \\
(0.2192)\end{array}$ & $\begin{array}{l}-0.3227 \\
(0.2096)\end{array}$ \\
\hline ICT & $\begin{array}{c}0.0056 \\
(0.0103)\end{array}$ & $\begin{array}{l}-0.0062 \\
(0.0125)\end{array}$ & $\begin{array}{c}0.0123 \\
(0.0121)\end{array}$ & $\begin{array}{l}-0.0052 \\
(0.0136)\end{array}$ & $\begin{array}{c}0.0012 \\
(0.0117)\end{array}$ & $\begin{array}{l}-0.0123 \\
(0.0142)\end{array}$ & $\begin{array}{c}0.1850 \\
(0.1853)\end{array}$ & $\begin{array}{c}-0.5229 \\
(0.2457)^{*}\end{array}$ \\
\hline Railway & $\begin{array}{l}-0.0517 \\
(0.0731)\end{array}$ & $\begin{array}{c}0.1389 \\
(0.1513)\end{array}$ & $\begin{array}{c}-0.0976 \\
(0.0817)\end{array}$ & $\begin{array}{c}0.2501 \\
(0.2092)\end{array}$ & $\begin{array}{l}-0.1212 \\
(0.0484)^{*}\end{array}$ & $\begin{array}{c}0.8283 \\
0.2865)^{* *}\end{array}$ & $\begin{array}{c}-0.1454 \\
(0.0630)^{*}\end{array}$ & $\begin{array}{c}-0.0213 \\
(0.1877)\end{array}$ \\
\hline _cons & $\begin{array}{c}9.1285 \\
(2.4004)^{* * *}\end{array}$ & $\begin{array}{l}-11.3119 \\
(20.7775)\end{array}$ & $\begin{array}{c}13.1828 \\
(3.8521)^{* *}\end{array}$ & $\begin{array}{l}-33.8846 \\
(24.5990)\end{array}$ & $\left(\begin{array}{l}12.4805 \\
3.5370)^{* *}\end{array}\right.$ & $\begin{array}{l}-27.7404 \\
31.8053)\end{array}$ & $\begin{array}{c}7.6480 \\
(4.6509)\end{array}$ & $\begin{array}{r}29.1815 \\
(40.2283)\end{array}$ \\
\hline $\begin{array}{l}N \\
\mathrm{r} 2\end{array}$ & 606 & $\begin{array}{c}606 \\
0.1380\end{array}$ & 498 & $\begin{array}{c}498 \\
0.1159\end{array}$ & 229 & $\begin{array}{c}229 \\
0.2856\end{array}$ & 108 & $\begin{array}{c}108 \\
0.5044\end{array}$ \\
\hline
\end{tabular}

BRI $(B R I)$ became statistically significant. Concretely, the coefficient $E U$ (column 8 in Table 3) is significant for Western Balkans, while BRI (column 5 in Table 3) has highly corresponded with EU-13. It reaffirmed the importance of trade costs (TCosts) and connectivity in determining the integration processes and FDI inflows to selected countries.

A negative sign of the $E U$ variable could be explained by the fact that EU enlargement determined more powerful by trade rather than FDI. Regarding China's BRI effects, the negative regression coefficient $B R I$ shows high risk of participation and determined mostly by infrastructure investment rather than FDI. Estimates of the impact of EU membership and BRI participation on FDI flows are mixed but in line with recent literature (Bruno et al., 2017; Chen \& Lin, 2018; Welfens \& Baier, 2018; Smarzynska \& Wei, 2000).

In general terms, the analysis proved that Europe and China are closely interconnected through trade and FDI. It means that stronger ties with China can be realized for EU-13 and Western Balkans at the cost of easing relations with the developed EU countries. 
To measure connectivity, similar to trade costs, we observe significant regional differences in physical infrastructure quality (Ports, Railway) as well as in digital infrastructure adequacy (Internet, ICT, HiTech). Infrastructure quality is found to matter: the results show a significant and positive relationship between port qualities (Ports) and FDI inflows in Western Balkans and railway (Railway) and FDI in EU-13. Clearly, countries with higher railway indices and better ports tend to attract a greater volume of FDI. For instance, as seen from Table 3, decreasing traffic by railway (Railway) and refining quality in $10 \%$ for EU-13 causes $1 \%$ increase in FDI flows. There are similar findings for Western Balkans: improving quality of ports (Ports) by 10 points is associated with $2 \%$ increase in FDI.

FDI involves not only the flow of goods but also the flow of information; hence, there is an important interplay between investment flows and the flows of ideas and knowhow (Jungbluth, 2019). High technology (HiTech), the technological progress and communication services (ICT) in the host country, the service of Internet provider (Internet) create a great platform for investment. Indeed, increasing Internet traffic (Internet) by $10 \%$ in all selected countries causes 3.5\% increase in FDI flows. So, there is a positive effect of digital connectivity on FDI.

Expectedly, all significant infrastructure indicators (Ports, Railway, Internet, ICT, HiTech) tend to be lowest for NMS and Western Balkans. Comparing these countries with EU-28, we notice that while the average infrastructure quality of NMS and Western Balkans is below that of high income countries, it might be a key determinant of the BRI participation.

\section{CONCLUSIONS AND POLICY IMPLICATIONS}

Determinants of FDI in Europe vary across countries and change their nature over time. Since countries have become the new EU member states or candidate countries, FDI increased sharply, making EU membership a particulate important FDI determinant. However, since 2013 the Belt and Road Initiative (BRI) has adopted, FDI to BRI countries increased sharply, making connectivity the main of the influential FDI factors. And today, in time of relocation and protectionist tendencies, connectivity and digital infrastructure will become dominant FDI factors.

In addition to existing studies, the model of FDI with Chinese influence in Europe was formulated and estimated, grouping advanced EU countries, NMS and Western Balkans and distinguishing between impacts of EU- and BRI-membership on FDI.

The EU, as a big and developed market, has always been interesting for China, first as a new market (horizontal FDI) and recently as a combination of horizontal and vertical models under the Knowledge Capital Model (KC). With EU enlargement, the new EU member states have become interesting markets for Chinese investors as a gateway to the developed EU countries. Western Balkans, as a candidate and neighboring countries, appear both as export-oriented and as a pre-entry destination to the EU (complex vertical or export-oriented FDI).

By applying panel data over 2000-2019 for 34 countries, which form $89 \%$ of all European FDI, we verify, among many determinants, the importance of EU membership and BRI participation for FDI, caused reducing trade costs and improving connectivity. 
Connectivity is the latest and modern tool for advancing influence in FDI. Trade costs as a proxy for connectivity with China have become one of the main FDI determinants in selected countries. Comparing trade costs indices, calculated for each year in the period 2000-2018 for 35 countries and their partners, we show that trade costs of NMS are lower concerning trade partners located within (EU-28) or closer to the region (Western Balkans). The analysis also indicated that intra-EU trade costs trended downwards after 2004, 2007, coinciding with EU enlargements. For Western Balkans, trade costs with China are relatively higher than with the EU but were dropped after 2013, with coming into effect of BRI.

Incorporating trade costs into baseline empirical model, we show that trade costs indicate the degree of European integration among the EU and candidate countries as well as between BRI countries. At the same time, trade costs provide measure for Chinese influence and the BRI efficiency in Europe. Specifically, if country properly uses BRI funds for improving infrastructure, it can further enhance the attractiveness of the country to FDI.

Chinese influence in the new EU member states felt more strongly than in all other countries across Europe. It means the negative relationship between trade costs and FDI turns out to be stronger for EU-13 than for Western Balkans. This implies that the new EU market is more attractive for Chinese infrastructure investment than Western Balkans.

In general terms, the analysis shows that Europe and China are closely interconnected through trade and FDI. It means that stronger ties with China can be realized for EU-13 and Western Balkans at the cost of easing relations with the developed EU countries.
The results obtained are of particular importance for the public policy decision makers, as the changes in FDI determinants require the adaptation of public policies in the selected countries. Richer countries are more preferential for FDI, but they have higher transportation and trade costs. In this context, if the country is attempting to attract more FDI, it would be reasonable to develop its infrastructure, production, and improve connectivity.

\section{References}

Asiedu, E. (2002). On the Determinants of Foreign Direct Investment to Developing Countries: Is Africa Different? World Development, 30 (1), 107-119.

Asiedu, E. (2006). Foreign Direct Investment in Africa: The Role of Natural Resources, Market Size, Government Policy, Institutions and Political Instability. The World Economy, 29 (1), 63-77.

Baltagi, B.H., Egger, P.H., \& Pfafermayr, M. (2007). Estimating Regional Trade Agreement Effects on FDI in an Interdependent World. Syracuse University Maxwell School of Citizenship and Public Affairs Center for Policy Research Working Paper No. 100. Retrieved from http://dx.doi.org/10.2139/ssrn.1809094

Bevan, A., Estrin, S., \& Meyer, K. (2004). Foreign investment location and institutional development in transition economies. International Business Review, 13 (1), 4364.

Blonigen, B.A., Davies, R.B., Waddell, G.R., \& Naughton, H.T. (2007). FDI in space: Spatial autoregressive relationships in foreign direct investment. European Economic Review, 51 (5), 1303-1335.

Bruno, R., Campos, N., Estrin, S., \& 


\title{
ДЕТЕРМИНАНТЕ СДИ У ЕВРОПИ И УТИЦАЈ КИНЕ
}

\begin{abstract}
Alena Dorakh
Извод

Упркос недавној забринутости због све већег утицаја спољних инвеститора на Европску унију (ЕУ) и западни Балкан, развијене европске земље и даље су доминантан извор страних директних инвестиција (СДИ) у региону, што потврђује користи од чланства у ЕУ. Истовремено, убрзано повезивање и нижи трговински трошкови у земљама које су у процесу приступања и суседним земљама одређују раст СДИ из Кине, посебно путем „Belt and Road Initiative“ (БРИ). Коришћењем панела података током 2000-2019 за 34 земље, које чине 89\% свих европских СДИ, прво се испитују обрасци СДИ широм Европе, упоређује се ЕУ са новим државама чланицама и западним Балканом; проверава се значај чланства у ЕУ за стране директне инвестиције, што доводи до смањења трговинских трошкова и побољшања повезаности. Стога се нове државе чланице ЕУ (HMC) и западни Балкан појављују и као матична држава и као претприступно одредиште у ЕУ. Затим, израчунавају се индекси трговинских трошкова за сваку одабрану земљу и партнере током времена и налази се да су Европа и Кина уско повезане трговином и СДИ. То значи да јаче везе са Кином, земље из истраживаног узорка, могу остварити по цену ублажавања односа са ЕУ. На крају, инкорпорирајући индексе трговинских трошкова у ФДИ модел, процењује се утицај повезаности на СДИ и процењује се како је БРИ утицао на СДИ у Европи. Поред тога, потврђено је да стари оквир хоризонталних и вертикалних СДИ није довољно репрезентативан, и да се чак и нове сложене вертикалне или извозно оријентисане СДИ стратегије данас се мењају.
\end{abstract}

Кључне речи: СДИ, трговински трошкови, повезаност, кинеске инвестиције, хоризонталне, вертикалне и извозно оријентисане стратегије, „Belt and Road Initiative“ (БРИ), фиксни и случајни ефекти

Meng, T. (2017). Economic integration, foreign investment and international trade: the effects of membership of the European Union. LSE Research Online Documents on Economics, London School of Economics and Political Science, LSE Library. Retrieved from https://EconPapers.repec.org/RePEc:ehl:1ser od:86615.

Canh, N.P., Binh, N.T., Thanh, S.D., \& Schinckus, C. (2020). Determinants of foreign direct investment inflows: The role of economic policy uncertainty. International Economics, 161 (C), 159-172.
Chen, M.X. \& Lin, C. (2018). Foreign Investment across the Belt and Road: Patterns, Determinants, and Effects. Policy Research Working Paper; No. 8607. World Bank. Retrieved from https://openknowledge.worldbank.org/handl e/10986/30577

Dunning, J.H. (1973). The Determinants of International Production. Oxford Economic Papers New Series, 25 (3), 289336.

Dunning, J.H., \& Lundan, S.M. (2008). Institutions and the OLI Paradigm of the Multinational Enterprise. Asia Pacific 
Journal of Management, 25 (4), 573-593.

Feenstra, R.C., Inklaar, R. \& Timmer, M. P. (2015). The Next Generation of the Penn World Table",American Economic Review, 105(10), 3150-3182. available for download at:www.ggdc.net/pwt $<$ https://www.rug.nl/gg dc/productivity/pwt/related-research $>$

Helpman, E. (1984). A Simple Theory of Trade With Multinational Corporations. Journal of Political Economy, 92 (3), 451471.

Helpman, E. (2006). Trade, FDI, and the Organization of Firms. Journal of Economic Literature, 44 (3), 589-630.

Jirasavetakul, L.F., \& Rahman, J. (2018). Foreign Direct Investment in New Member States of the EU and Western Balkans: Taking Stock and Assessing Prospects. IMF Working Papers, 18/187.

Jungbluth, C. (2019). Tracing three decades of foreign direct investment booms and busts and their recent decline. Blog global Economic Dynamics. Retrieved from https://ged-project.de/allgemein-en/foreigndirect-investment/

Kano, L., \& Oh, C.H. (2020). Global Value Chains in the Post COVID World: Governance for Reliability. Journal of Management Studies, 57 (8), 1773-1777.

Markusen, J.R. (1984). Multinationals, Multi-plant Economies, and the Gains from Trade. Journal of International Economics, 16 (3-4), 205-226.

Markusen, J.R. (2000). Foreign Direct Investment, CIES Working Paper No. 19. Retrieved from http://dx.doi.org/10.2139/ssrn.231202

Markusen, J. R. (2002). Multinational firms and the theory of international trade. Cambridge: MIT Press.

Mistura, F., \& Roulet, C. (2019). The determinants of Foreign Direct Investment: Do statutory restrictions matter?, OECD
Working Papers on International Investment, No. 2019/01. OECD Publishing, Paris, France.

Novy, D. (2011). Gravity Redux: Measuring International Trade Costs with Panel Data. CESifo Working Paper Series No. 3616, CESifo. Retrieved from https://ideas.repec.org/p/ces/ceswps/_3616.h tml

Smarzynska, B.K., \& Wie, S.J. (2000). Corruption and Composition of Foreign Direct Investment: Firm-Level Evidence, Policy Research Working Paper, No. 2360. World Bank, Washington, DC.

Welfens, P.J.J., \& Baier, F.J. (2018). BREXIT and Foreign Direct Investment: Key Issues and New Empirical Findings. International Journal of Financial Studies, 6 (2), 46-67.

World investment report. (2020). Retrieved from: https://unctad.org/en/PublicationsLibrary/wi r2020_en.pdf 